\title{
Addressing gender imbalance in intensive care
}

\author{
Jean-Louis Vincent ${ }^{1 *}$ (0), Nicole P. Juffermans ${ }^{2,3}$, Karen E. A. Burns ${ }^{4,5,6}$, V. Marco Ranieri ${ }^{7}$, Chryssa Pourzitaki ${ }^{8}$ and \\ Francesca Rubulotta ${ }^{9,10}$ (1)
}

\begin{abstract}
There is a large gender gap in critical care medicine with women underrepresented, particularly in positions of leadership. Yet gender diversity better reflects the current critical care community and has multiple beneficial effects at individual and societal levels. In this Viewpoint, we discuss some of the reasons for the persistent gender imbalance in critical care medicine, and suggest some possible strategies to help achieve greater equity and inclusion. An explicit and consistent focus on eliminating gender inequity is needed until gender diversity and inclusion become the norms in critical care medicine.
\end{abstract}

Keywords: Diversity, Equity, Inclusion, Stereotypes, Motherhood, Bias, Mentorship

\section{Introduction: the current gender imbalance in critical care medicine}

Medicine has traditionally been a male-dominated profession. Despite women medical trainees outnumbering men medical trainees in many countries, there are still more men than women in clinical and academic leadership positions around the world [1]. Recent articles have highlighted this gender gap in the field of critical care medicine. In Australia, although $41 \%$ of trainee intensivists were women in 2018 (an increase from the $32 \%$ reported in 2013), only $12 \%$ of intensive care unit (ICU) directors were women [2]. In the USA in 2017, $33 \%$ of critical care trainees and $26 \%$ of ICU physicians were women [3]. Similarly, in the UK, $39 \%$ of trainee intensivists and $20 \%$ of ICU consultants were women [4]. According to Godier et al. [5], just 9\% of full professors in anesthesiology-intensive care in France were women in 2018; only $0.7 \%$ of the 605 presidents of medical commissions from public hospitals in France and none of the medical university deans were women

\footnotetext{
*Correspondence: jlvincent@intensive.org

${ }^{1}$ Department of Intensive Care, Erasme Hospital, Université Libre de Bruxelles, Route de Lennik 808, 1070 Brussels, Belgium

Full list of author information is available at the end of the article
}

anesthesiology-intensive care physicians [5]. Leadership in critical care societies is also still largely dominated by men. In the French Society of Anesthesia and Intensive Care (SFAR), $42 \%$ of the members were women in 2020 [5]. By contrast, in Northern Greece, $70 \%$ of intensivists are women and the Board of the Society of Anesthesiology and Intensive Care of Northern Greece is comprised exclusively of women (personal communication, Chryssa Pourzitaki).

Publication of research is considered essential for academic career advancement in medicine, and the number of publications influences the authors' visibility as researchers, their success as grant applicants [6] and their overall research productivity [7]. However, less than one-third of first authors of published critical care manuscripts are women and only one-fourth of senior authors [8]. Moreover, when the first author is a woman, articles tend to be published in lower-impact journals [8]. The proportion of women authors in the critical care literature has not changed substantially over the past decade [8]. Women are also less likely than men to sit on editorial boards of scientific journals, be faculty members at international conferences, or take part in expert panels [9-11]. Compared to men, women at all career stages are original author(s) and the source, provide a link to the Creative Commons licence, and indicate if changes were made. The images or other third party material in this article are included in the article's Creative Commons licence, unless indicated otherwise in a credit line to the material. If material is not included in the article's Creative Commons licence and your intended use is not permitted by statutory regulation or exceeds the permitted use, you will need to obtain permission directly from the copyright holder. To view a copy of this licence, visit http://creativecommons.org/licenses/by/4.0/. The Creative Commons Public Domain Dedication waiver (http://creativeco mmons.org/publicdomain/zero/1.0/) applies to the data made available in this article, unless otherwise stated in a credit line to the data. 
more likely to leave academia, with postdoctoral trainees and those early in their careers recognized to be at particularly high risk $[5,12]$.

\section{Understanding gender imbalance and potential strategies to address the gender gap in critical care medicine}

The reasons for the persistent gender imbalance in critical care medicine have been studied extensively over recent years. Societal ideas pertaining to the roles traditionally occupied by men and women have likely contributed. In a survey of 115 faculty and 122 undergraduate students at large, research intensive universities, agentic traits (pertaining to independence and self-assertion and stereotypically linked to men) were thought to be more important than communal traits (pertaining to concern for others and interpersonal sensitivity and stereotypically linked to women) for success in science [13]. Other biased perceptions include the belief that women are not suitable to handle acute situations, cannot perform long or out-of-office hours, and are not natural leaders [12]. In a survey of 283 American anesthesiologists who were asked to make a collaborative decision, Helzer and colleagues found that when treatment advice was delivered by an inexperienced physician, participants reported relying significantly more on the advice of a man versus a woman. Of interest, although participants' reliance on advice from a woman physician was a function of her experience, reliance on advice from a man physician was not [14]. Importantly, these biases are reinforced through repetitive exposure to stereotypical images seen in social and work groups and in the media, and by the frequent underrepresentation of women speakers at international meetings and in leadership positions.

Parsons Leigh and colleagues described institutional (lack of flexibility and limited job prospects) and interpersonal (bias against women) factors as key drivers of the gender gap in critical care medicine [1]. At the institutional level, changes must be made to enhance opportunities for promotion and leadership of women and to create the conditions necessary for women to have successful careers (Table 1). Organizations can promote gender equity and enhance inclusion by developing effective, appropriate and sustainable gender mainstreaming strategies that can be implemented, monitored, compared and updated as required [15]. Women still face workplace harassment and discrimination, from patients as well as other members of staff, and institutions are beginning to implement preventive and supportive strategies, although these remain rare. Greater visibility of women (increased numbers of women speakers and women in leadership positions and at the highest academic ranks) will provide more role models and mentors for future generations of women intensivists. Several programs (e.g., "Womentors" in Greece and "Wāhine Connect" in New Zealand) have been established to connect women in leadership positions with women lower down the career ladder for mentorship and support. However, promoting gender equity through greater visibility of women in leadership positions is challenging and organizations have not yet closed the gap sufficiently

Table 1 Some methods to improve gender balance at all levels of critical care medicine

\begin{tabular}{|c|c|}
\hline Level & Method to improve gender balance \\
\hline Institutional & $\begin{array}{l}\text { Establish and enforce codes of conduct in universities, hospitals, critical care societies } \\
\text { Create institutional diversity working groups } \\
\text { Ensure gender balance in committees and as speakers at conferences and scientific events (apply quota if deemed appropriate) } \\
\text { Be transparent when developing pathways to promotion }\end{array}$ \\
\hline Education & $\begin{array}{l}\text { Provide training on gender equity and bias for all ICU professionals, starting at medical school/nursing college } \\
\text { Develop a mentorship program to support and encourage junior female staff }\end{array}$ \\
\hline Pay gap & Pay men and women equally and publish metrics of salaries and gender diversity in scientific, academic and research activities \\
\hline Leadership & $\begin{array}{l}\text { Ensure women are given the same responsibilities in the workplace as their male counterparts: rounds, seminars, family discus- } \\
\text { sions, etc } \\
\text { Promote female intensivists as role models } \\
\text { Actively call out to women to apply for leadership roles, e.g., to become ICU director } \\
\text { Consider, if not already in place, introducing term limits for leadership positions }\end{array}$ \\
\hline Biases* and barriers & $\begin{array}{l}\text { Identify and eliminate implicit and subconscious bias to create a safe working environment } \\
\text { Provide a supportive, flexible environment for optimal balance between professional and family life for both men and women } \\
\text { Provide conditions like maternity leave and in-hospital nursery schools in order to facilitate female intensivists during their early } \\
\text { motherhood period } \\
\text { Encourage women to apply for grants and awards (possibly by giving them alternately to a male and female intensivist) } \\
\text { Develop objective criteria for hiring, evaluation, and promotion to limit effects of implicit and subconscious bias }\end{array}$ \\
\hline
\end{tabular}

*For the purpose of this manuscript the meaning of bias is the tendency to prefer one gender over another. It is a form of unconscious bias, or implicit bias, which occurs when one individual unconsciously attributes certain attitudes and stereotypes to another person or group of people 
to enable this approach alone to be effective. The use of quotas can be considered, but is associated with several limitations, including reinforcing the continued perception that men represent the norm and women are "outsiders" [16].

Another important area that needs to be addressed is the tension that many women experience between the different roles they hold at work and at home. The challenges of taking time away from medicine for maternity leave have been widely recognized and discussed $[17,18]$. There is still a belief, held by many, that it is not possible for women to have a successful medical career and a family, although for men this is not recognized or perceived to be an issue. Rita Levi Montalcini was an Italian neurologist who received the Nobel Price for Physiology and Medicine in 1986. A recent reconstruction of her biography highlights that Professor Montalcini asked her father to allow her to pursue her studies and to accept that she would not have a family [19]. This perceived "need to choose" affects women in fields other than medicine, including law, athletics and the performing arts. As a society, we need to name and include motherhood and fatherhood as part of the cultural norm during career progression. At the institutional level, we need to acknowledge that these issues exist and develop strategies to address the consequences that maternity may have on a woman's career. A first step may be the introduction of a "factor that corrects" for maternity leave in the quantitative analysis of scientific productivity. In a systematic review by Hoffman et al. [17], strategies for assisting women balance motherhood and medicine included the need for workplaces with policies for expanded childcare and breastfeeding facilities and institutions that promoted flexibility in the workplace. An additional approach would be to require men to take parental leave, which may help break down the concept that childcare is a woman's responsibility.

Within national and international critical care societies, several initiatives have been introduced to encourage gender balance, including selective endorsement of meetings that have gender diverse speakers. The Canadian Critical Care Society Diversity Policy strives to achieve at least 30\% (ideally $30-40 \%$ ) women speakers. A similar policy developed by the Australia New Zealand Intensive Care Society aims to include $50 \%$ women speakers by 2022 . The European Society of Intensive Care Medicine (ESICM) has introduced several task forces to address gender inequality. In the absence of international registries, it remains challenging for critical care societies to benchmark or compare their diversity metrics to those of others.

\section{Conclusion}

The focus of this Viewpoint has been to highlight the need to promote gender equity and inclusion in critical care medicine and suggest some possible strategies to help achieve greater equity and inclusion. It is our collective responsibility, as a critical care community, to identify and address barriers that perpetuate inequities in critical care. Diversity and code of conduct policies have been adopted by several critical care societies and the World Federation of Societies of Intensive and Critical Care Medicine. Widespread adoption of such policies will help eliminate inequity and enhance inclusion. Training and mentorship programs for women intensivists will enable promotion of women to higher academic ranks and leadership positions. Acknowledging the existence of implicit and explicit biases is an essential first step. We believe that an explicit focus on eliminating gender inequity will help to gradually change societal views of the roles played by women and men critical care physicians so that it will become the norm for women and men to be both critical care physicians and leaders in critical care.

\section{Abbreviation \\ ICU: Intensive care unit. \\ Acknowledgements \\ We would like to thank Pascale Gruber, Marie Cruz Martin Delgado, Karin Amrein and Marcela Paola Vizcaychipi for their constructive input when preparing this manuscript.}

\section{Authors' contributions}

JLV and FR wrote the first draft. NPJ, KB, VMR, and CP critically revised the manuscript. All authors read and approved the final manuscript.

\section{Funding}

None.

Availability of data and materials

Not applicable.

\section{Declarations}

Ethics approval and consent to participate Not applicable.

\section{Consent for publication \\ Not applicable.}

\section{Competing interests}

JLV is Editor-in-Chief of Critical Care. The other authors declare that they have no relevant competing interest.

\footnotetext{
Author details

${ }^{1}$ Department of Intensive Care, Erasme Hospital, Université Libre de Bruxelles, Route de Lennik 808, 1070 Brussels, Belgium. ${ }^{2}$ Laboratory of Experimental Intensive Care and Anaesthesiology, Amsterdam University Medical Centre, Location Academic Medical Centre, Amsterdam, The Netherlands. ${ }^{3}$ Department of Intensive Care, OLVG Hospital, Amsterdam, The Netherlands.

${ }^{4}$ Interdepartmental Division of Critical Care Medicine, University of Toronto, Toronto, ON, Canada. ${ }^{5}$ Unity Health Toronto-St. Michael's Hospital, Toronto, ON, Canada. ${ }^{6}$ Li Ka Shing Knowledge Institute, St. Michael's Hospital, Toronto, ON, Canada. ${ }^{7}$ Dipartimento di Scienze Mediche e Chirurgiche, Anesthesia
} 
and Intensive Care Medicine, Alma Mater Studiorum, Università di Bologna Policlinico di Sant'Orsola, Bologna, Italy. ${ }^{8}$ Department of Anesthesiology and ICU, School of Health Sciences, Faculty of Medicine, Aristotle University of Thessaloniki, 54124 Thessaloniki, Greece. ${ }^{9}$ Department of Anaesthesia and Intensive Care Medicine, Imperial College London, London, UK. ${ }^{10}$ Chair of the International Women in Intensive \& Critical Care Medicine Network, Catania, Italy.

Received: 22 December 2020 Accepted: 7 April 2021

Published online: 16 April 2021

\section{References}

1. Leigh JP, Grood C, Ahmed SB, Ulrich AC, Fiest KM, Straus SE, et al. Toward gender equity in critical care medicine: a qualitative study of perceived drivers, implications, and strategies. Crit Care Med. 2019;47:e286-91.

2. WIN ANZICS. How are women represented in Intensive Care? https:// www.womenintensive.org/copy-of-metrics. Accessed 30 March 2021.

3. Association of American Medical Colleges. 2018 Physician Specialty Data Report. https://www.aamc.org/system/files/2019-08/2018executivesu mmary.pdf. Accessed 30 March 2021.

4. The Faculty of Intensive Care Medicine. WICM (Women in ICM). https:// www.ficm.ac.uk/wicm. Accessed 30 March 2021.

5. Godier A, Nouette-Gaulain K, Cittanova ML, Beloeil H, Paugam-Burtz C, Lukaszewicz AC. Women in anaesthesia and intensive care medicine in France: are we making any progress? Anaesth Crit Care Pain Med. 2020;39:507-11.

6. Burns KEA, Straus SE, Liu K, Rizvi L, Guyatt G. Gender differences in grant and personnel award funding rates at the Canadian Institutes of Health Research based on research content area: a retrospective analysis. PLoS Med. 2019;16:e1002935

7. Jagsi R, DeCastro R, Griffith KA, Rangarajan S, Churchill C, Stewart A, et al. Similarities and differences in the career trajectories of male and female career development award recipients. Acad Med. 2011;86:1415-21.

8. Vranas KC, Ouyang D, Lin AL, Slatore CG, Sullivan DR, Kerlin MP, et al. Gender differences in authorship of critical care literature. Am J Respir Crit Care Med. 2020;201:840-7.
9. Venkatesh B, Mehta S, Angus DC, Finfer S, Machado FR, Marshall J, et al. Women in Intensive Care study: a preliminary assessment of international data on female representation in the ICU physician workforce, leadership and academic positions. Crit Care. 2018;22:211

10. Janssen KT, Urbach HM, Ham KR, Wewerka SS, Bach PB, Cooke CR, et al. The gender gap in critical care task force participation. Lancet Respir Med. 2019;7:566-7.

11. Merman E, Pincus D, Bell C, Goldberg N, Luca S, Jakab M, et al. Differences in clinical practice guideline authorship by gender. Lancet. 2018;392:1626-8

12. Bismark M, Morris J, Thomas L, Loh E, Phelps G, Dickinson H. Reasons and remedies for under-representation of women in medical leadership roles: a qualitative study from Australia. BMJ Open. 2015;5:e009384.

13. Ramsey LR. Agentic traits are associated with success in science more than communal traits. Person Individ Differ. 2017;106:6-9.

14. Helzer EG, Myers CG, Fahim C, Sutcliffe KM, Abernathy JH. Gender bias in collaborative medical decision making: emergent evidence. Acad Med. 2020;95:1524-8.

15. European Institute for Gender Equality. Gender mainstreaming: a guide to organisational change. https://eige.europa.eu/gender-mainstream ing/toolkits/gender-institutional-transformation/gender-mainstreamingguide-organisational-change. Accessed 3 March 2021.

16. Murray R. Quotas for men: reframing gender quotas as a means of improving representation for all. Am Pol Sci Rev. 2014;108:520-32.

17. Hoffman R, Mullan J, Nguyen M, Bonney AD. Motherhood and medicine: systematic review of the experiences of mothers who are doctors. Med J Aust. 2020;213:329-34

18. Flynn B, Stiles K, Fritzel A, Weyker P, Ivascu N, Nazir N, et al. Survey of workplace perceptions of female anesthesiologists. Anesth Essays Res. 2020;14:177-82.

19. Rita Levi-Montalcini. www.raiplay.it/programmi/ritalevi-montalcini. Accessed 12 March 21.

\section{Publisher's Note}

Springer Nature remains neutral with regard to jurisdictional claims in published maps and institutional affiliations.
Ready to submit your research? Choose BMC and benefit from:

- fast, convenient online submission

- thorough peer review by experienced researchers in your field

- rapid publication on acceptance

- support for research data, including large and complex data types

- gold Open Access which fosters wider collaboration and increased citations

- maximum visibility for your research: over 100M website views per year

At $B M C$, research is always in progress.

Learn more biomedcentral.com/submissions 